\title{
Control of Phytoplankton Growth by Iron Supply and Irradiance in the Subantarctic Southern Ocean: Experimental Results From the SAZ Project
}

P.W. Boyd
A. C. Crossley
G. R. DiTullio
F. B. Griffiths
D. A. Hutchins

See next page for additional authors

Follow this and additional works at: https://digitalcommons.odu.edu/oeas_fac_pubs

Part of the Biogeochemistry Commons, Marine Biology Commons, and the Oceanography Commons

\section{Repository Citation}

Boyd, P. W.; Crossley, A. C.; DiTullio, G. R.; Griffiths, F. B.; Hutchins, D. A.; Queguiner, B.; Sedwick, Peter N.; and Trull, T. W., "Control of Phytoplankton Growth by Iron Supply and Irradiance in the Subantarctic Southern Ocean: Experimental Results From the SAZ Project" (2001). OEAS Faculty Publications. 83.

https://digitalcommons.odu.edu/oeas_fac_pubs/83

\section{Original Publication Citation}

Boyd, P.W., Crossley, A.C., DiTullio, G.R., Griffiths, F.B., Hutchins, D.A., Queguiner, B., .. Trull, T.W. (2001). Control of phytoplankton growth by iron supply and irradiance in the subantarctic Southern Ocean: Experimental results from the SAZ project. Journal of Geophysical Research-Oceans, 106(C12), 31573-31583. doi: 10.1029/2000JC000348 
Authors

P. W. Boyd, A. C. Crossley, G. R. DiTullio, F. B. Griffiths, D. A. Hutchins, B. Queguiner, Peter N. Sedwick, and T.W. Trull 


\title{
Control of phytoplankton growth by iron supply and irradiance in the subantarctic Southern Ocean: Experimental results from the SAZ Project
}

\author{
P. W. Boyd, ${ }^{1}$ A. C. Crossley, ${ }^{2}$ G. R. DiTullio, ${ }^{3}$ F. B. Griffiths, ${ }^{4}$ D. A. Hutchins, ${ }^{5}$ \\ B. Queguiner, ${ }^{6}$ P. N. Sedwick, ${ }^{7}$ and T. W. Trull ${ }^{7}$
}

\begin{abstract}
The influence of irradiance and iron ( $\mathrm{Fe}$ ) supply on phytoplankton processes was investigated, north $\left(47^{\circ} \mathrm{S}, 142^{\circ} \mathrm{E}\right)$ and south $\left(54^{\circ} \mathrm{S}, 142^{\circ} \mathrm{E}\right)$ of the Subantarctic Front in austral autumn (March 1998). At both sites, resident cells exhibited nutrient stress $\left(F_{v} /\right.$ $F_{m}<0.3$ ). Shipboard perturbation experiments examined two light (mean in situ and elevated) and two $\mathrm{Fe}$ (nominally 0.5 and $3 \mathrm{nM}$ ) treatments under silicic acid-replete conditions. Mean in situ light levels (derived from incident irradiances, mixed layer depths (MLDs), wind stress, and a published vertical mixing model) differed at the two sites, 25\% of incident irradiance $I_{0}$ at $47^{\circ} \mathrm{S}$ and $9 \% I_{0}$ at $54^{\circ} \mathrm{S}$ because of MLDs of $40\left(47^{\circ} \mathrm{S}\right)$ and $90 \mathrm{~m}\left(54^{\circ} \mathrm{S}\right)$, when these stations were occupied. The greater MLD at $54^{\circ} \mathrm{S}$ is reflected by tenfold higher cellular chlorophyll $a$ levels in the resident phytoplankton. In the $47^{\circ} \mathrm{S}$ experiment, chlorophyll $a$ levels increased to $>1 \mu \mathrm{g} \mathrm{L}{ }^{-1}$ only in the high-Fe treatments, regardless of irradiance levels, suggesting Fe limitation. This trend was also noted for cell abundances, silica production, and carbon fixation rates. In contrast, in the $54^{\circ} \mathrm{S}$ experiment there were increases in chlorophyll $a$ (to $>2 \mu \mathrm{g} \mathrm{L}^{-1}$ ), cell abundances, silica production, and carbon fixation only in the high-light treatments to which $\mathrm{Fe}$ had been added, suggesting that $\mathrm{Fe}$ and irradiance limit algal growth rates. Irradiance by altering algal Fe quotas is a key determinant of algal growth rate at $54^{\circ} \mathrm{S}$ (when silicic acid levels are nonlimiting); however, because of the integral nature of Fe/light colimitation and the restricted nature of the current data set, it was not possible to ascertain the relative contributions of $\mathrm{Fe}$ and irradiance to the control of phytoplankton growth. On the basis of a climatology of summer mean MLD for subantarctic (SA) waters south of Australia the $47^{\circ}$ and $54^{\circ} \mathrm{S}$ sites appear to represent minimum and maximum MLDs, where $\mathrm{Fe}$ and $\mathrm{Fe} /$ irradiance, respectively, may limit/colimit algal growth. The implications for changes in the factors limiting algal growth with season in SA waters are discussed.
\end{abstract}

\section{Introduction}

The role of iron $(\mathrm{Fe})$ in controlling phytoplankton growth rate has been demonstrated in the high-nitrate, low-chlorophyll (HNLC) regions of the equatorial Pacific [Kolber et al., 1994; Coale et al., 1996a, 1996b] and NE subarctic Pacific Ocean [Martin et al., 1989; Coale, 1991; Boyd et al., 1996] from in situ and shipboard $\mathrm{Fe}$ enrichments, respectively. In the Southern Ocean, shipboard $\mathrm{Fe}$ enrichments have also exhibited Fe-elevated algal biomass, but in many studies there were

${ }^{1}$ Centre for Chemical and Physical Oceanography, National Institute of Water and Atmospheric Research, Department of Chemistry, University of Otago, Dunedin, New Zealand.

${ }^{2}$ Institute of Antarctic and Southern Ocean Studies, University of Tasmania, Hobart, Tasmania, Australia.

${ }^{3}$ Grice Marine Laboratory, University of Charleston, Charleston, South Carolina, USA.

${ }^{4}$ CSIRO Division of Marine Research, Hobart, Tasmania, Australia.

${ }^{5}$ College of Marine Studies, University of Delaware, Lewes, Delaware, USA.

${ }^{6}$ Laboratoire d'Oceanographie et de Biogeochimie, Centre d'Oceanologie de Marseille, UMR CNRS 6535, Marseille, France.

${ }^{7}$ Antarctic CRC, Hobart, Tasmania, Australia.

Copyright 2001 by the American Geophysical Union.

Paper number 2000JC000348.

0148-0227/01/2000JC000348\$09.00 significant increases in chlorophyll (i.e., $>1.5 \mu \mathrm{g} \mathrm{L}^{-1}$ ) in control treatments [see de Baar and Boyd, 2000]. Indirect evidence of the role of iron supply was provided by de Baar et al. [1995], who demonstrated a positive relationship between the magnitude of in situ phytoplankton stocks and ambient Fe levels in the vicinity of the Polar Front (PF) in the South Atlantic. Furthermore, Timmermans et al. [1998] and Boyd et al. [1999] have presented physiological evidence of Fe-stressed resident phytoplankton in the Atlantic PF region and in subantarctic (SA) waters, respectively. Recently, unequivocal evidence for the role of $\mathrm{Fe}$ in controlling algal growth rates in the Southern Ocean was provided by the Southern Ocean Iron Release Experiment (SOIREE) in situ mesoscale iron fertilization [Boyd et al., 2000].

Despite this confirmation of the important role of $\mathrm{Fe}$ in the open Southern Ocean [Boyd et al., 2000] the existence of deep mixed layers in this region [Mitchell et al., 1991; Nelson and Smith, 1991] and the antagonistic relationship between algal light limitation and Fe limitation [Raven, 1990; Sunda and Huntsman, 1997] means that light limitation or Fe/light colimitation may control phytoplankton growth at times and in various regions in Southern Ocean waters. Raven [1990] used predicted cellular Fe contents and $\mathrm{Fe}$ acquisition rates of cultured phytoplankton to estimate that the $\mathrm{Fe}$ requirements of cells growing under light limitation were 50 -fold higher than 
Table 1. A Comparison of the Main Chemical, Physical, and Biological Properties Under Ambient Conditions (Sampled From $20 \mathrm{~m}$ Depth) at the $47^{\circ}$ and $54^{\circ} \mathrm{S}$ Sites ${ }^{\mathrm{a}}$

\begin{tabular}{|c|c|c|c|}
\hline Parameter & Units & $47^{\circ} \mathrm{S}$ & $54^{\circ} \mathrm{S}$ \\
\hline Mixed layer depth & $\mathbf{m}$ & 40 & 90 \\
\hline Attenuance, $K_{d}$ & $\mathrm{~m}^{-1}$ & 0.055 & 0.041 \\
\hline Daily incident PAR & mol quanta $\mathrm{m}^{-2} \mathrm{~d}^{-1}$ & 24 & 19 \\
\hline Mean wind stress & knots & 18 & 24 \\
\hline Temperature & $\mathrm{C}$ & 11 & 4 \\
\hline Chl $a$ & $\mu \mathrm{g} \mathrm{L}^{-1}$ & 0.2 & 0.15 \\
\hline Nitrate & $\mu \mathrm{mol} \mathrm{L} \mathrm{L}^{-1}$ & $>8$ & $>25$ \\
\hline Silicic acid & $\mu \mathrm{mol} \mathrm{L^{-1 }}$ & 0.9 & 2.5 \\
\hline $\mathrm{DFe}$ & nmol L $L^{-1}$ & 0.07 & $0.07^{\mathrm{b}}$ \\
\hline Cyanobacterial abundance & $\times 10^{3}$ cells $\mathrm{mL}^{-1}$ & 30 & 1 \\
\hline$F_{v} / F_{m}$ & dimensionless & 0.3 & 0.25 \\
\hline Cellular Chl $a$ & fg cell ${ }^{-1}$ & 6.6 & 50.1 \\
\hline C fixation & $\mu \mathrm{mol} \mathrm{C} \mathrm{L}{ }^{-1} \mathrm{~d}^{-1}$ & 0.84 & 0.34 \\
\hline$P_{\max }$ & $\mu \mathrm{mol} \mathrm{C} \mathrm{L} \mathrm{L}^{-1} \mathrm{~h}^{-1}$ & 0.18 & 0.04 \\
\hline$P_{\text {bmax }}^{\max }$ & $\mu \mathrm{g} \mathrm{C} \mu \mathrm{g} \mathrm{Chl} a^{-1} \mathrm{~h}^{-1}$ & 9.2 & 2.1 \\
\hline Biogenic silica & $\mu \mathrm{mol} \mathrm{L} \mathbf{L}^{-1}$ & 0.07 & 0.53 \\
\hline Silica production & $\mathrm{nmol} \mathrm{Si} \mathrm{L}^{-1} \mathrm{~d}^{-1}$ & 18.0 & 9.0 \\
\hline Fe uptake & fmol Fe $\mathrm{mL}^{-1} \mathrm{~h}^{-1}$ & 2.5 & 2.3 \\
\hline Fe:C uptake ratio & $\mathrm{pmol}: \mu \mathrm{mol}$ & 52.0 & 78.0 \\
\hline C:Si uptake ratio & Mol:mol & 46.7 & 37.8 \\
\hline
\end{tabular}

aPAR, photosynthetically active radiation; Chl $a$, chlorophyll $a$.

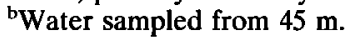

under light-saturated growth. These estimates were confirmed for algal lab cultures by Sunda and Huntsman [1997], who demonstrated that in addition to irradiance, algal cell size played a role in determining cellular Fe requirements. Maldonado et al. [1999] demonstrated Fe/light colimitation of algal growth during winter deckboard experiments in the NE subarctic Pacific. Investigators have jointly considered the influence of $\mathrm{Fe} /$ light on phytoplankton processes in Southern Ocean waters but report conflicting results. Deckboard studies [van Leeuwe, 1996; Boyd et al., 1999, 2000] observed Fe/light colimitation, whereas Takeda [1998] reported no significant difference in iron-elevated growth rate when cells were incubated under high or low irradiances (see section 4.3).

The present study took place in SA waters south of Australia, a region characterized by subnanomolar dissolved $\mathrm{Fe}$ (DFe) [Sedwick et al., 1997], low silicic acid levels [Zentara and Kamykowski, 1981], and deep surface mixed layers [Rintoul et al., 1997]. The objective of this study was to determine what factor(s) controls algal growth rates in SA waters. However, because of the potentially confounding influences of concurrent $\mathrm{Fe}$ and light/silicic acid limitation on algal processes in austral autumn, two sets of complementary shipboard perturbation experiments were performed in which either silicic ac$\mathrm{id} / \mathrm{Fe}$ or Fe/irradiance levels was altered. This paper reports on the $\mathrm{Fe}$ /irradiance experiments, while results from the silicic acid/Fe experiments are summarized by Sedwick et al. [1999] and presented in detail by Hutchins et al. [this issue].

\section{Methods}

Fe/irradiance perturbation experiments of 7 and 10 day duration were performed on board RSV Aurora Australis in the vicinity of $47^{\circ}$ and $54^{\circ} \mathrm{S}\left(142^{\circ} \mathrm{E}\right)$, respectively (see map) [Rintoul and Trull, this issue]. Water was sampled from $20 \mathrm{~m}$ depth using a "clean" pump with the subsurface intake flushed for 1 hour prior to sampling [Hutchins and Bruland, 1998]. Pumped seawater was collected within a clean environment (submicron filtered air, laminar flow), and $25 \mathrm{~L}$ clean polycarbonate car- boys were rinsed and then filled with seawater. Samples were taken from this supply for time zero measurements. Five treatments were prepared: treatments 1-3 were incubated under mean in situ irradiance: unamended seawater (control), low-Fe enrichment (low Fe, low light), high-Fe enrichment (high Fe, low light); while treatments $4-5$ were incubated under greater than mean in situ irradiance, low-Fe enrichment (low Fe, high light), and high-Fe enrichment (high $\mathrm{Fe}$, high light).

Low- ( $0.5 \mathrm{nM} \mathrm{Fe})$ and high-Fe ( $3 \mathrm{nM} \mathrm{Fe})$ enrichments were added as $\mathrm{FeCl}_{2}$ chelated with ethylene diamine tetra acetic acid (EDTA) in a 1:1.5 ratio [Coale, 1991]. In the "low-light" treatment, cells were exposed to a light level corresponding to the in situ mean irradiance received daily as they are vertically mixed in the upper ocean. In the "high-light" treatment, cells were exposed to a higher than mean in situ irradiance. Mean in situ irradiance levels were estimated using shipboard data on mixed layer depth (MLD), mean wind stress, water column light attenuance, and incident irradiance $I_{0}$, in conjunction with equations for the vertical displacement of phytoplankton by turbulent mixing [Denman and Gargett, 1983]. At the relatively high wind stresses recorded (Table 1), it was assumed that cells circulated throughout the surface mixed layer, rather than circulating within eddies of length scales less than the MLD [see MacIntyre, 1998].

The estimated in situ irradiances, expressed as a percentage of daily incident irradiance $I_{0}$, for the low- (and high-) light treatments in the $47^{\circ}$ and $54^{\circ} \mathrm{S}$ experiments were $25 \% I_{0}\left(50 \% I_{0}\right)$ and $9 \% I_{0}\left(25 \% I_{0}\right)$, respectively. Carboys were enclosed in neutral density screening equivalent to the calculated $\% I_{0}$. A single $25 \mathrm{~L}$ carboy was used per treatment (as opposed to multiple $4 \mathrm{~L}$ bottles) to minimize containment artifacts such as wall effects [Berg $e t$ al., 1999] during the long-term (up to 10 days) incubations required in subpolar waters. Thus there are no true replicate treatments. However, there are pseudoreplicates for subsamples $\left({ }^{55} \mathrm{Fe},{ }^{14} \mathrm{C}\right.$, and $\left.{ }^{32} \mathrm{Si}\right)$, and the trends observed from independent techniques (chlorophyll $a,{ }^{14} \mathrm{C}$, and ${ }^{32} \mathrm{Si}$ ) may be compared.

In March 1998, surface ambient silicic acid levels were low, in the range of concentrations known to limit diatom growth 
$\left(<1 \mu \mathrm{M}\left(47^{\circ} \mathrm{S}\right)\right.$ and $\left.2.4 \mu \mathrm{M}\left(54^{\circ} \mathrm{S}\right)\right)$ [Paasche, 1973] and may have confounded the study of Fe/irradiance on algal growth. Therefore silicic acid (chelex-100 purified) [Sedwick et al., 1999] was added to all carboys (final concentration $3.5 \mu \mathrm{M}$, comparable to winter reserve [Boyd et al., 1999]). After spiking with $\mathrm{Fe} /$ silicic acid the neck and cap of each carboy was sealed with parafilm. Carboys were incubated on deck in pumped surface seawater, and incubator temperatures were monitored. Carboys were subsampled (class 100 clean air conditions) at noon on $t=2.25,5.25,7.25$ days $\left(47^{\circ} \mathrm{S}\right)$ and $t=2.25,6.25$, and 10.25 days $\left(54^{\circ} \mathrm{S}\right)$.

Seawater subsamples were analyzed using active fluorescence (fast repetition rate fluorometry $(t=0$ only [after Kolber and Falkowski, 1993]), size-fractionated chlorophyll $a$ (>20, 5-20, 2-5, and 0.2-2 $\mu \mathrm{m}$ fractions) following Joint and Pomroy [1983], flow cytometry (see below), biogenic silica [Quéguiner, this issue], and DFe [Sedwick et al., 1997]. Phosphate, silicic acid, and nitrate + nitrite levels were analyzed using an Alpkem Flow Solution Analyser. Rate measurements included ${ }^{14} \mathrm{C}$ uptake [Joint et al., 1993], ${ }^{55} \mathrm{Fe}$ uptake [Schmidt and Hutchins, 1999], algal silica production using ${ }^{32} \mathrm{Si}$ [Brzezinski and Phillips, 1997], and photosynthesis:irradiance $(P: I)$ characteristics [Mackey et al., 1995]. Subsamples for rate measurements were incubated for 24 hours on deck at the same $\% I_{0}$ as used for the corresponding carboy (except for the 1 hour $P: I$ incubations).

Cell abundances were analyzed using a Becton Dickinson FACScan flow cytometer with a $15 \mathrm{~mW}$ argon ion laser. Flow rate and size calibration were determined using Fluoresbrite beads and lab-cultured cells such as Synechococcus [Olson et al., 1993]. Two-dimensional scatterplots of FL2 (orange fluorescence) and FL3 (red fluorescence) provided estimates of the medium/large strongly red autofluorescent cells (e.g., diatoms) and cyanobacteria [Wright et al., 1991, 1996; Crossley, 1998]. Although flow cytometry describes fluorescence intensity rather than direct measurement of cell size, size calibration experiments indicate that $2 \mu \mathrm{m}$ diameter is the cutoff between small and medium/large cells. These categories were used, in conjunction with size-fractionated chlorophyll $a$ to estimate cellular chlorophyll $a$ for prokaryotes and eukaryotes.

Algal net growth rates were estimated using the instantaneous change in chlorophyll $a$ or in cell abundance. Estimates of diatom net growth rates were obtained from silica turnover (silica production/biogenic silica). Two general experimental artefacts must be noted. First, DFe levels from a vertical profile at $54^{\circ} \mathrm{S}$ [Sedwick et al., 1999] were considerably lower than those in carboys at $54^{\circ} \mathrm{S}$, suggesting inadvertent Fe contamination of carboy seawater. Thus, for $54^{\circ} \mathrm{S}$ there was no "low-Fe" treatment, and this experiment must be viewed as an investigation of the effects of altering irradiance levels on (initially Fe-stressed) cells under Fe-replete conditions. Second, there was no high-light control carboy at either site; this may have implications at the $54^{\circ} \mathrm{S}$ site (see section 4.2).

\section{Results}

\subsection{Physical, Chemical, and Biological Properties}

The $47^{\circ} \mathrm{S}$ site at the time of sampling had a seasonal MLD of $80 \mathrm{~m}$ with evidence of a transient mixed layer $(0-40 \mathrm{~m}$, Figure 1a). Surface temperature was $11.5^{\circ} \mathrm{C}$, and noon incident irradiances were $350 \mu \mathrm{mol}$ quanta $\mathrm{m}^{-2} \mathrm{~s}^{-1}$ (Figure 1b). Surface nitrate + nitrite levels were $>8 \mu \mathrm{mol} \mathrm{L} \mathrm{L}^{-1}$, silicic acid was $<1$ $\mu \mathrm{mol} \mathrm{L} \mathrm{L}^{-1}$, and DFe was $<0.1 \mathrm{nmol} \mathrm{L}^{-1}$ (Table 1). Despite the presence of a transient mixed layer, chlorophyll $a$ was $0.2 \mu \mathrm{g}$ $\mathrm{L}^{-1}$ from 0 to $75 \mathrm{~m}$ (see section 4.1, Figure 1c). The cells $<2$ $\mu \mathrm{m}$ that dominated chlorophyll $a$ were cyanobacteria such as Synechococcus (Table 1). The algal community had suboptimal values of $F_{v} / F_{m}$ (Table 1), suggesting impaired photosynthetic competence due to nutrient stress. Estimated cellular chlorophyll $a$ was $6.6,3.8$, and $20 \mathrm{fg} \mathrm{cell}^{-1}$ for cells $>0.2,0.2-2$ (mainum prokaryotes), and $>2 \mu \mathrm{m}$ (eukaryotes), respectively.

South of the SA Front at $54^{\circ} \mathrm{S}$, temperatures were $4.4^{\circ} \mathrm{C}$ in a $90 \mathrm{~m}$ MLD. Surface nitrate levels were $>25$ and $2.5 \mu \mathrm{mol} \mathrm{L} \mathrm{L}^{-1}$ for silicic acid (Table 1). DFe levels were 0.07 and $0.11 \mathrm{nmol}$ $\mathrm{L}^{-1}$ at 45 and $75 \mathrm{~m}$ depth, respectively. Chlorophyll $a$ was 0.15 $\mu \mathrm{g} \mathrm{L}^{-1}$, with a subsurface chlorophyll $a$ maximum (SCM) just below the mixed layer (Figure 1d). Cells $<2 \mu \mathrm{m}$ (cyanobacteria) and $>20 \mu \mathrm{m}$ (diatoms) dominated chlorophyll $a$ in the upper $90 \mathrm{~m}$, while diatoms were dominant in the SCM. $F_{v} / F_{m}$ in surface waters $(0.25)$ was indicative of a resource-limited algal assemblage (Table 1). Cellular chlorophyll $a$ were 50,62, and $46 \mathrm{fg} \mathrm{cell}^{-1}$ for cells $>0.2,0.2-2$, and $>2 \mu \mathrm{m}$, respectively. Note, this cellular chlorophyll $a$ content for picophytoplankton corresponds to around $6 \%$ of their dry matter. Despite similar chlorophyll $a$ levels between sites, biogenic silica levels were considerably higher at the $54^{\circ} \mathrm{S}$ site (Table 1 ). Rates of carbon fixation and silica production were higher at $47^{\circ} \mathrm{S}$ compared to $54^{\circ} \mathrm{S}$, whereas Fe uptake was similar at both sites.

\subsection{The $47^{\circ} \mathrm{S}$ Perturbation Experiment}

The high-Fe treatments exhibited the greatest increase in chlorophyll $a$ levels at $47^{\circ} \mathrm{S}$ with little change in the other treatments over 7 days (Figure 2a). This trend was supported by flow cytometric and rate measurements. Cyanobacterial abundances doubled in the high-Fe treatments by day 4 (Figure $2 \mathrm{c}$ ), and diatom abundances increased $>$ sixfold over 7 days (Figure 2e). Nitrate levels decreased by $2.5-4.5 \mu \mathrm{mol} \mathrm{L}^{-1}$ in the high-Fe treatments but changed little in the others (data not shown). DFe levels in the control were $0.3 \mathrm{nmol} \mathrm{L}^{-1}$, suggesting minor contamination, whereas the low-Fe and high-Fe treatments contained 0.7 and $2.7 \mathrm{nmol} \mathrm{L}^{-1} \mathrm{DFe}$ on day 2 , respectively (Table 2 ).

While chlorophyll $a$ levels increased over 7 days for both high-Fe treatments, rates of carbon fixation leveled on day 4 after initially quintupling (Figure 3a). Again, there was little change in production rates in the other treatments. Cells $>5$ $\mu \mathrm{m}$ were responsible for $40 \%$ of production in both high-Fe treatments (data not shown). The initial uptake of $\mathrm{Fe}$ was greatest in both high-Fe treatments, but the temporal trends were less clear (Figure 3c) than for carbon fixation or silica production. Fe:C uptake ratios generally decreased several fold after time zero in all treatments for all cells (data not shown). Silica production rates were pronounced only in the high-Fe treatments, increasing slightly between days 0 and 4, then markedly after 4 days (Figure $3 \mathrm{e}$ ). This uptake pattern differs from that for $\mathrm{C}$ fixation.

$\mathrm{Fe}$ enrichment (high-Fe treatments) resulted in a doubling of cellular chlorophyll $a(>0.2 \mu \mathrm{m})$ after 7 days, whereas levels changed little for the control/low-Fe treatments (Figure 4a). Cellular chlorophyll $a(0.2-2 \mu \mathrm{m})$ doubled in all treatments, while levels remained constant or declined for $>2 \mu \mathrm{m}$ cells in carboys over 7 days. There were fourfold increases in the light-saturated photosynthesis rate $\left(P_{\max }\right)$ in both high-Fe treatments over 7 days (not shown); however, trends in $P_{\text {bmax }}$ (normalized to chlorophyll $a$ ) were less clear (Figure 4c). $P_{\mathrm{b}}^{\prime}$ max (normalized to algal abundance) exhibited similar trends to 

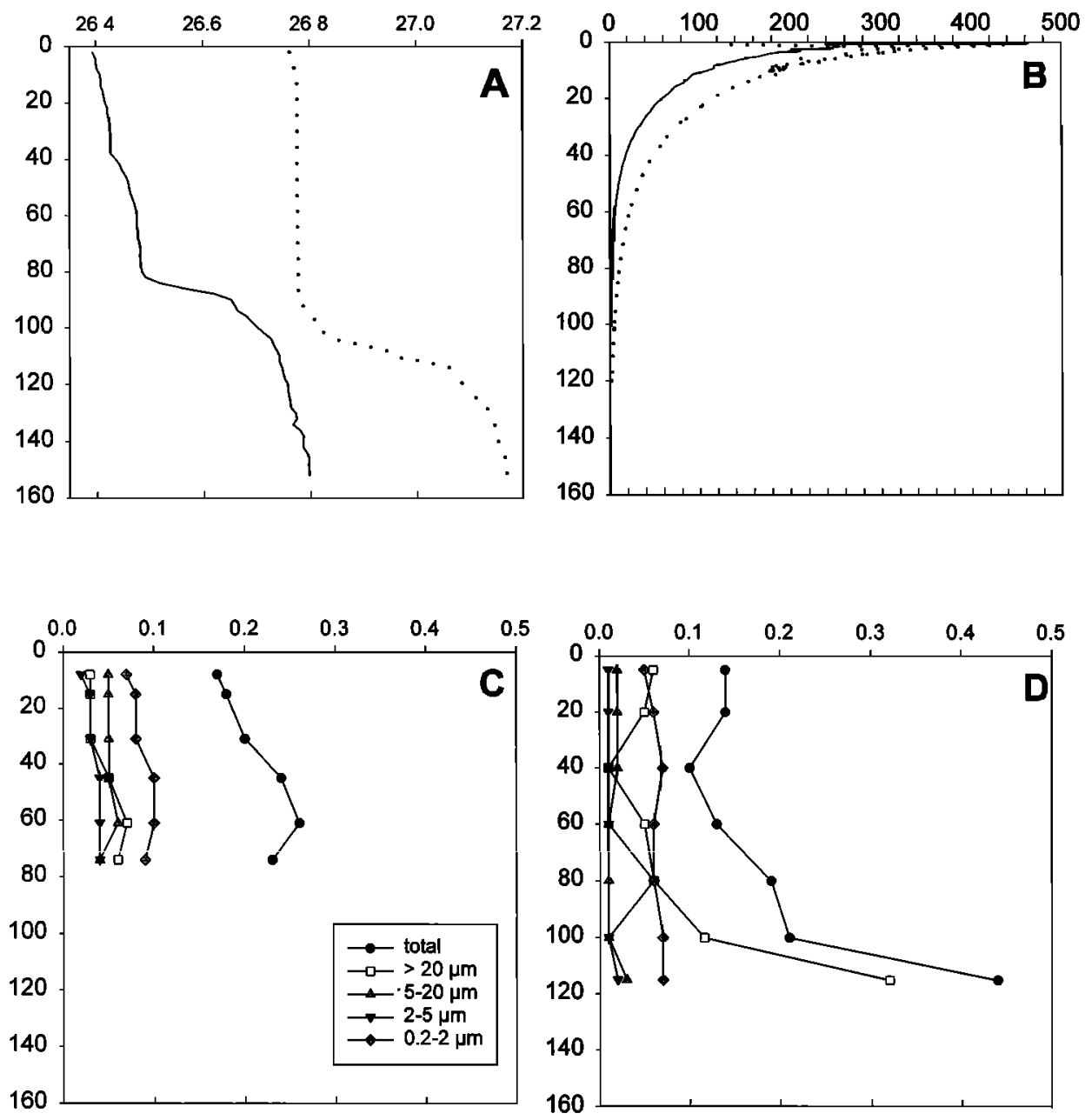

Figure 1. Vertical profiles of (a) sigma theta at the $47^{\circ} \mathrm{S}$ (March 9, 1998, solid line) and $54^{\circ} \mathrm{S}$ sites (March 18, 1998, dotted line); (b) photosynthetically active radiation (PAR) at the $47^{\circ}$ and $54^{\circ}$ sites; and the partitioning of chlorophyll $a$ into 4 size fractions at (c) $47^{\circ}$ and (d) $54^{\circ}$ S. No replicates. PAR was profiled with a Biospherical Instruments PRR-600 reflectance radiometer at local noon, with the vessel orientated toward the Sun to minimize ship shadow.

$P_{\max }$ for both high Fe treatments (Figure 4e). Photoinhibition was not observed during the $47^{\circ} \mathrm{S}$ experiment.

Algal (net) growth rates (from chlorophyll $a$ ) were 0.7 doublings $\mathrm{d}^{-1}$ by days 2 and 4 in the high-Fe/high-light and high$\mathrm{Fe} /$ low-light treatments, respectively, and decreased thereafter (Table 3a). Net growth rates were generally low for the other treatments. In contrast, net growth rates (from cell abundance) were $\sim 0.2-0.3$ doublings $\mathrm{d}^{-1}$ after 48 hours for the high-Fe treatments and lower for the others (Table $3 \mathrm{~b}$ ).

\subsection{The $54^{\circ} \mathrm{S}$ Perturbation Experiment}

In contrast to the $47^{\circ} \mathrm{S}$ experiment, chlorophyll $a$ levels increased markedly only in both high-light treatments (either $>1$ or $3 \mathrm{nmol} \mathrm{L}{ }^{-1} \mathrm{Fe}$ was added, Table 2 ), and the lag prior to an increase in chlorophyll $a$ was 4 days longer (Figure 2b). Total cell abundance increased fourfold in both high-light treatments because of fivefold and twofold increases in cyanobacterial and diatom abundances, respectively (Figures $2 \mathrm{~d}$ and $2 \mathrm{f}$ ). This trend was supported by other measurements, with rates of carbon fixation increasing markedly only in the high-light carboys (Figure $3 \mathrm{~b}$ ). Initial production rates were half those at $47^{\circ} \mathrm{S}$ but were comparable in magnitude by day 10 in the
high-Fe/high-light treatment. As in the $47^{\circ} \mathrm{S}$ experiment, cells $>5 \mu \mathrm{m}$ were responsible for $40 \%$ of carbon fixation in the high-Fe/high-light carboy (data not shown).

Initial rates of $\mathrm{Fe}$ uptake were similar at both sites (Table 1); however, uptake patterns differed between sites (Figures 3c and 3d). Both high-Fe treatments exhibited the highest initial increase in $\mathrm{Fe}$ uptake at $54^{\circ} \mathrm{S}$. Despite higher biogenic silica levels at the $54^{\circ} \mathrm{S}$ site, silica production rates were initially higher at $47^{\circ} \mathrm{S}$ than at $54^{\circ} \mathrm{S}$ (Table 1) and exhibited the highest increases in the high-light treatments (Figure 3f). Cellular chlorophyll $a$ quadrupled in both high-light treatments by day 10 at $54^{\circ} \mathrm{S}$ (Figure $4 \mathrm{~b}$ ). Cellular chlorophyll $a$ declined in cells $<2 \mu \mathrm{m}$ over 10 days but increased in cells $>2 \mu \mathrm{m}$, particularly for the high-light treatments (data not shown).

In contrast to $47^{\circ} \mathrm{S}, P_{\max }$ at $54^{\circ} \mathrm{S}$ was initially fivefold lower (Table 1). As for other measurements at $54^{\circ} \mathrm{S}, P_{\max }$ increased only in the high-light treatments (data not shown). $P_{\text {bmax }}$ (chlorophyll $a$ ) exhibited initial increases in all carboys, followed by a progressive decrease, with little difference in the magnitude of $P_{\text {bmax }}$ between treatments (Figure $4 \mathrm{~d}$ ). $P_{\text {bmax }}^{\prime}$ increased greater than fivefold only in both high-light treatments at $54^{\circ} \mathrm{S}$ (Figure 4f). There was photoinhibition in incubated samples at 

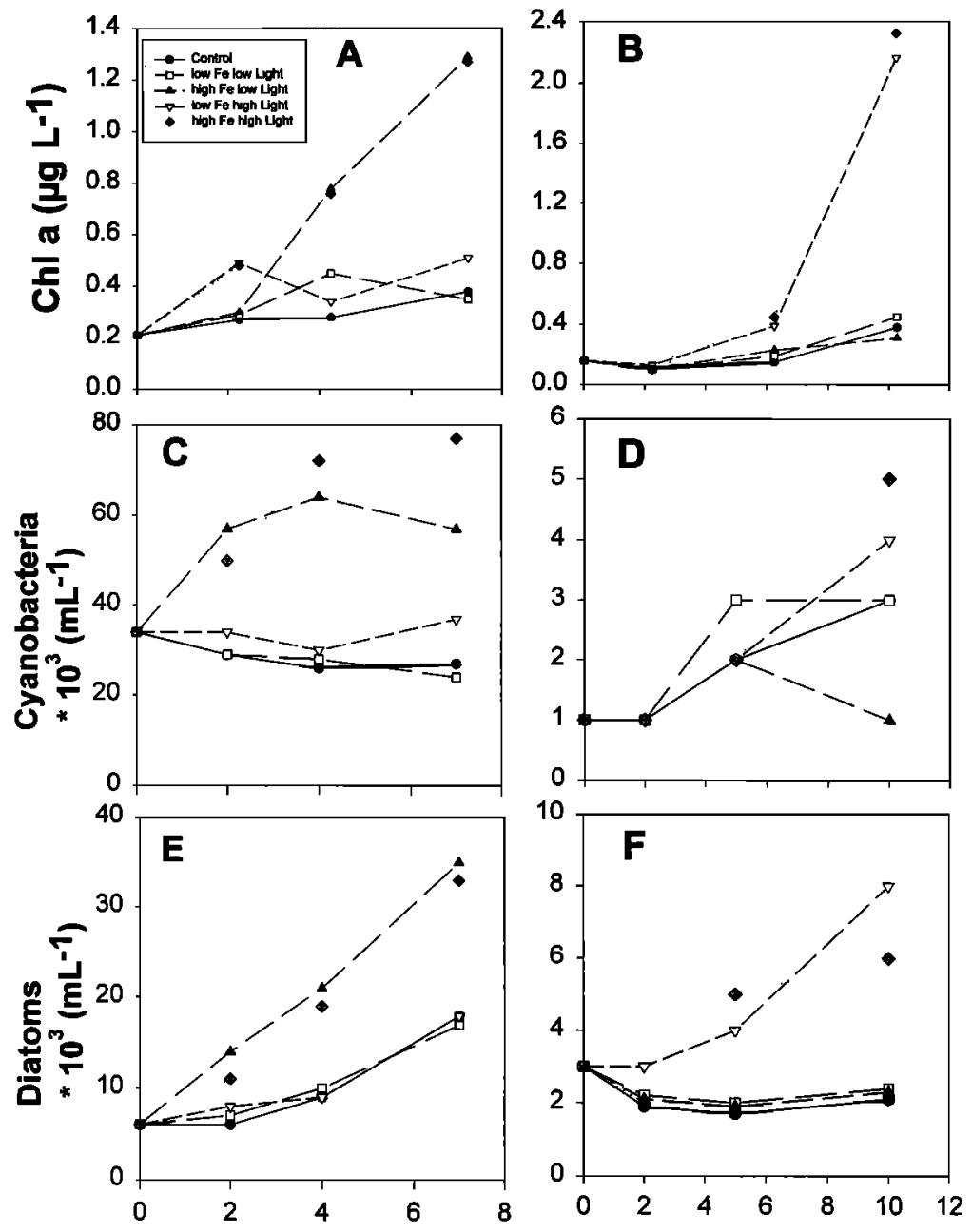

\section{Days}

Figure 2. Changes in (a) chlorophyll $a$ levels $(>0.2 \mu \mathrm{m}$ ), (c) cyanobacterial abundances, and (e) diatom abundances with time during the Fe/irradiance perturbation experiments at the $47^{\circ}$ site. Changes in these respective properties at the $54^{\circ} \mathrm{S}$ site are presented in Figures $2 \mathrm{~b}, 2 \mathrm{~d}$, and $2 \mathrm{f}$. Time zero for experiments was March 9, $1998\left(47^{\circ} \mathrm{S}\right)$, and March 18, $1998\left(54^{\circ} \mathrm{S}\right)$. Carboys were also sampled at 1400 hours on March 11, 14, and $16\left(47^{\circ} \mathrm{S}\right)$, and 1400 hours on March 20,24 , and $28\left(54^{\circ} \mathrm{S}\right)$. Diatom abundances were obtained from counts of medium/large single red fluorescent cells (SRFCs), which are mainly characterized by diatoms.

$54^{\circ} \mathrm{S}$; on day $2, P_{\text {bmax }}$ was depressed at $>200 \mu \mathrm{mol}$ quanta $\mathrm{m}^{-2}$ $\mathrm{s}^{-1}$ for all treatments.

Growth rates (chl $a$ specific, net) increased primarily in the high-light treatments, attaining $0.5-0.8$ doublings $\mathrm{d}^{-1}$ by day 6 and $>1$ doublings $\mathrm{d}^{-1}$ after 10 days (Table $3 \mathrm{a}$ ). In contrast, net specific growth rates (cell abundance) were $\sim 0.2$ doublings $\mathrm{d}^{-1}$ in the high-light treatments between days 6 and 10 (Table $3 b$ ). Diatom growth rates were generally 0.1 doublings $\mathrm{d}^{-1}$ or less

Table 2. Dissolved Fe Levels at $t=0$ (From $20 \mathrm{~m}$ Depth) and in the Experimental Carboys During the $47^{\circ}$ and $54^{\circ} \mathrm{S}$ Experiments $^{\mathrm{a}}$

\begin{tabular}{|c|c|c|c|c|c|c|c|c|}
\hline \multirow[b]{2}{*}{ Treatment } & \multicolumn{4}{|c|}{$47^{\circ} \mathrm{S}$} & \multicolumn{4}{|c|}{$54^{\circ} \mathrm{S}$} \\
\hline & $t=0$ & $t=2$ & $t=4$ & $t=7$ & $t=0$ & $t=2$ & $t=6$ & $t=10$ \\
\hline Control & 0.07 & 0.30 & 0.35 & 0.30 & $0.97^{*}$ & 1.56 & 1.02 & 0.72 \\
\hline Low-Fe/low-light & & 0.63 & 0.64 & 0.51 & & 0.72 & 0.46 & 0.40 \\
\hline High-Fe/low-light & & 2.70 & 2.02 & 1.88 & & 3.14 & 2.15 & 1.93 \\
\hline Low-Fe/high-light & & 0.68 & 0.45 & 0.96 & & 1.39 & 0.57 & 0.45 \\
\hline High-Fe/high-light & & 2.81 & 2.02 & 1.88 & & 3.77 & 1.35 & 0.67 \\
\hline
\end{tabular}

${ }^{\mathrm{a}} \mathrm{Fe}$ levels are in $\mathrm{nmol} \mathrm{L}{ }^{-1}$. An asterisk denotes (initial) Fe contamination of the carboy. Note these are the maximum DFe levels for each carboy, as the DFe analysis was performed on subsamples taken from each carboy. Coale [1991] has reported contamination occurring during such transfer procedures. 

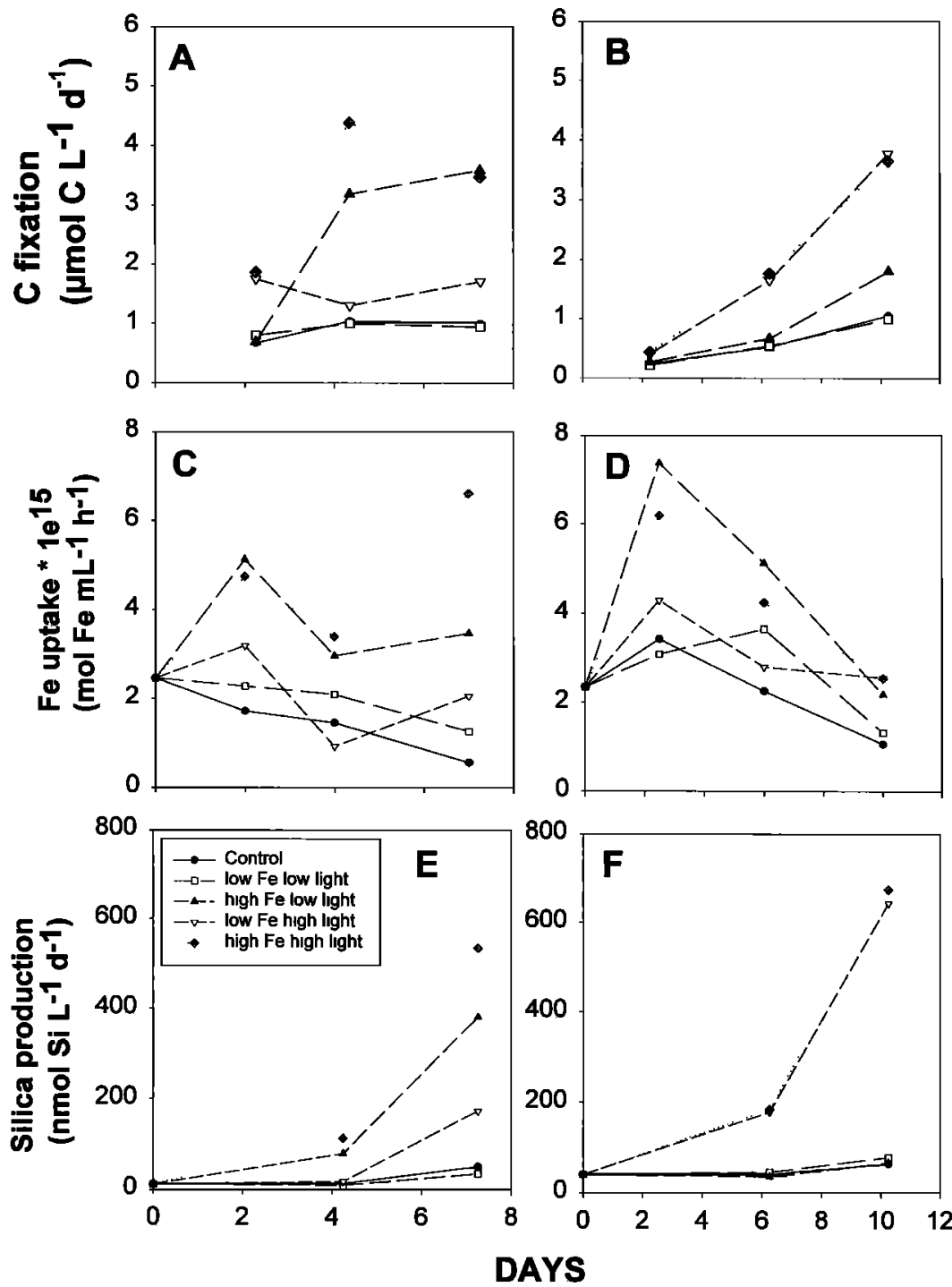

Figure 3. Changes in community rates of (a) carbon fixation, (c) Fe uptake, and (e) silica production during the $\mathrm{Fe} /$ irradiance perturbation experiments at $47^{\circ}$. Changes in these respective properties at the $54^{\circ} \mathrm{S}$ site are presented in Figures 3b, 3d, and 3f. Variation between pseudoreplicates (in all panels) was $<10 \%$ in all cases.

for all treatments but increased to 0.3 doublings $d^{-1}$ in the high-light treatments by day 10 (data not shown).

\section{Discussion}

\subsection{Comparison Between Conditions at the $47^{\circ}$ and $54^{\circ} \mathrm{S}$} Sites

SA waters comprise around half of the areal extent of icefree waters of the Southern Ocean [Boyd et al., 1999]. The $47^{\circ}$ and $54^{\circ} \mathrm{S}$ sites were located in the water masses north and south of the SA Front, respectively [Rintoul and Trull, this issue] and therefore provide snapshots of the properties of the different water masses in the subpolar Southern Ocean. The main physical differences between sites were water temperature and MLD (Table 1). The $7^{\circ} \mathrm{C}$ decrease in temperature between sites was likely responsible for the thirtyfold decrease in cyanobacterial abundances at $54^{\circ} \mathrm{S}$. Marchant et al. [1987] reported temperature to be the main determinant of cyanobac- terial abundance in waters between Australia and Antarctica. The reduced temperatures at $54^{\circ} \mathrm{S}$ were probably also responsible, in part, for the reduced physiological rates (such as carbon fixation) recorded at this site, relative to the $47^{\circ} \mathrm{S}$ site [see Banse, 1991].

There are no strong latitudinal trends in summer mean MLD in SA waters (Plate 1). Thus the MLDs at $47^{\circ}$ and $54^{\circ} \mathrm{S}$ when the stations were occupied may be due to local forcing. Indeed, at $47^{\circ} \mathrm{S}$, similar chlorophyll $a$ levels from 0 to $75 \mathrm{~m}$ and differences in both temperature and salinity between the $0-40$ $\mathrm{m}$ and $40-80 \mathrm{~m}$ depth horizons (data not shown) are indicative of horizontal advection of a less dense water mass into this region. While this feature at $47^{\circ} \mathrm{S}$ may have been transient, nevertheless, it was characterized by cells genetically adapted to a higher light regime compared with phytoplankton at $54^{\circ} \mathrm{S}$, which had ninefold higher cellular chlorophyll $a$ (higher for both size fractions), indicative of increased light-harvesting requirements for the resident cells at $54^{\circ} \mathrm{S}$. Thus the $47^{\circ} \mathrm{S}$ site 

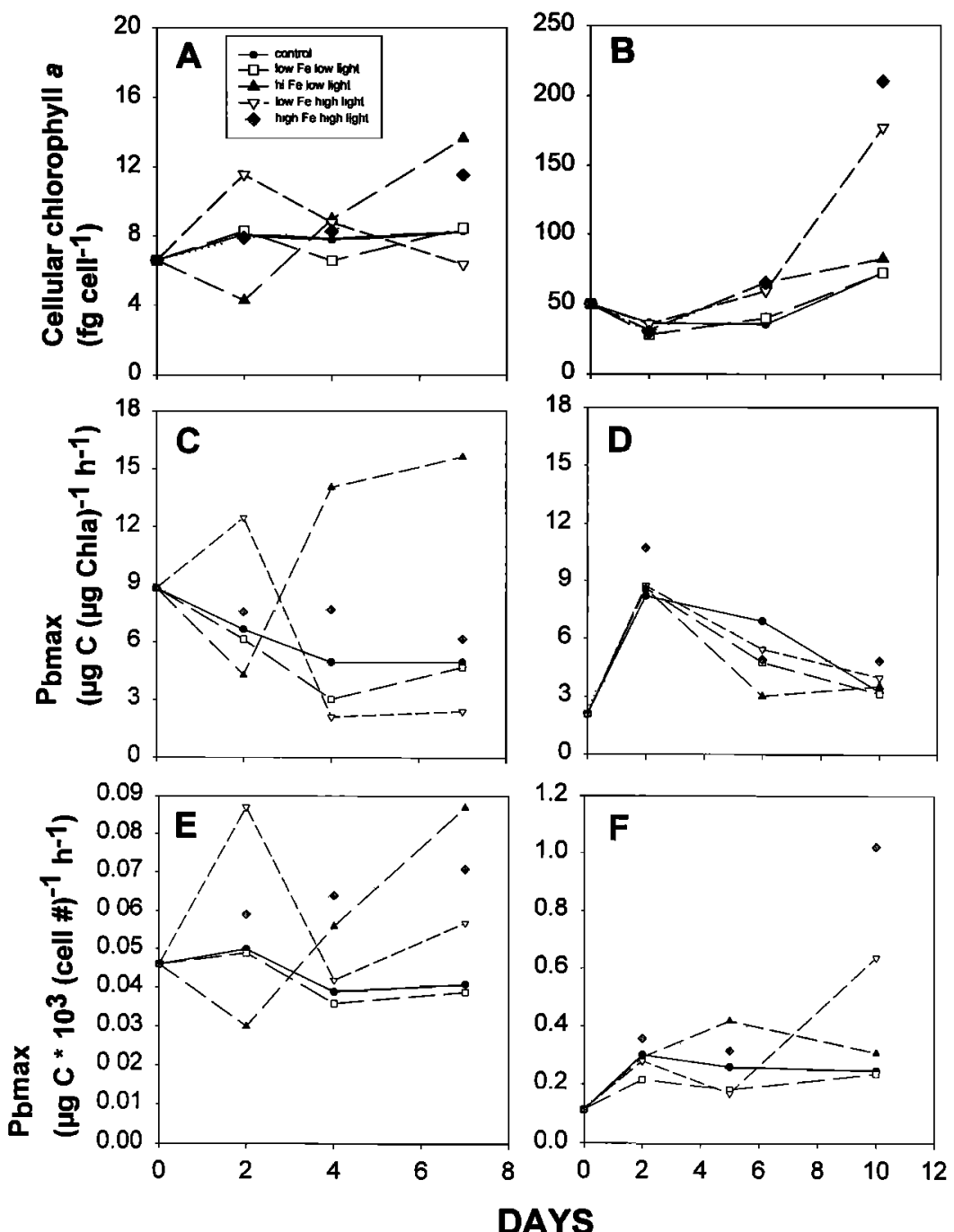

Figure 4. Changes in cellular chlorophyll $a$ of the algal community at (a) $47^{\circ}$ and (b) $54^{\circ} S$ sites. Changes in the light-saturated photosynthetic rate of the phytoplankton assemblage with time during the Fe/irradiance perturbation experiments for $P_{\mathrm{bmax}}$ (normalized to chlorophyll) at the (c) $47^{\circ}$ and (d) $54^{\circ} \mathrm{S}$ site and for $P_{\mathrm{bmax}}^{\prime}$ (normalized to cell abundance) at the (e) $47^{\circ} \mathrm{S}$ and (f) $54^{\circ} \mathrm{S}$ site. Note, different scales are used for $P_{\mathrm{bmax}}^{\prime}$ because of differences in cell abundance at each site. The standard error of the estimation of $P_{\mathrm{bmax}} P_{\mathrm{bmax}}^{\prime}$ was generally $<5 \%$.

provided a contrasting "inoculum" of cells acclimated to a different light environment than were cells from the $54^{\circ} \mathrm{S}$ site for the Fe/light experiments.

In March 1998 each site was probably characterized by highnitrate, low-silicic acid, low-chlorophyll (HNLSLC) [Dugdale et al., 1995] conditions, as predicted for SA waters late in the growth season [Boyd et al., 1999]. Observed DFe levels at 47 and $54^{\circ} \mathrm{S}$ were low and comparable to those previously reported in this region [Sedwick et al., 1997] and in SA waters SE of New Zealand [Boyd et al., 1999]. There was evidence of nutrient-stressed resident cells at both sites $\left(F_{v} / F_{m}=0.25\right)$, which was due to either low-Fe levels and/or low-silicic acid levels [see Lippemeier et al., 1999]. Hutchin et al. [this issue] report evidence from deckboard experiments of iron/silicic acid colimitation of algal growth rates of the resident cells at $47^{\circ} \mathrm{S}$. As no data are available from $\mathrm{Fe} / \mathrm{Si}$ deckboard perturbations or on the kinetics of silica production at $54^{\circ} \mathrm{S}$, it is not known whether silicic acid supply limited algal growth rates at the $54^{\circ} \mathrm{S}$ site. However, it is likely that the resident cells were Fe-stressed at both sites given that ambient DFe levels were tenfold less than the threshold for Fe stress $\left(1.0 \mathrm{nmol} \mathrm{Fe} \mathrm{kg}{ }^{-1}\right)$, as indicated by flavodoxin expression, in SA waters [see Boyd et al., 1999, Figure 5d]. Thus there is evidence of silicic acid/Fe stress of the resident cells at the $47^{\circ} \mathrm{S}$ site and of both Fe stress and light limitation (enhanced light-harvesting abilities, lower rates of carbon fixation and $P_{\max }$ ) for resident cells at the $54^{\circ} \mathrm{S}$ site.

\subsection{Comparison of the Fe/Light Perturbation Experiments}

There were clear differences in the outcomes of the two experiments, with only high-Fe supply ( $>2 \mathrm{nmol} \mathrm{L}{ }^{-1}$, regardless of mean light levels) mediating increases both in algal stocks and in the magnitude of rate processes in the $47^{\circ} \mathrm{S}$ experiment. Significant increases in algal stocks/rate processes were observed only in the high-light treatments in the $54^{\circ} \mathrm{S}$ experiment; noting that, because of contamination, all treatments were probably Fe-replete at $54^{\circ} \mathrm{S}$. On the basis of the observed physiological properties of the resident cells at the two sites (see Table 1), the mean in situ light levels at the two sites was likely the key determinant of the different experimental outcomes. 
Table 3a. Phytoplankton Growth Rates (Doublings $\mathrm{d}^{-1}$ ) Estimated From Instantaneous Change in Chlorophyll $a$ Levels (Net Growth) ${ }^{\mathbf{a}}$

\begin{tabular}{|c|c|c|c|c|c|c|}
\hline \multirow[b]{2}{*}{ Treatment } & \multicolumn{3}{|c|}{$47^{\circ} \mathrm{S}$} & \multicolumn{3}{|c|}{$54^{\circ} \mathrm{S}$} \\
\hline & $t=2$ & $t=4$ & $t=7$ & $t=2$ & $t=6$ & $t=10$ \\
\hline Control & 0.13 & 0.02 & 0.12 & -0.16 & 0.11 & 0.36 \\
\hline Low-Fe/low-light & 0.19 & 0.29 & -0.07 & -0.19 & 0.24 & 0.32 \\
\hline High-Fe/low-light & 0.22 & 0.79 & 0.22 & -0.18 & 0.29 & 0.09 \\
\hline Low-Fe/high-light & 0.67 & -0.15 & 0.16 & -0.10 & 0.51 & 1.13 \\
\hline High-Fe/high-light & 0.63 & 0.30 & 0.22 & -0.18 & 0.83 & 1.04 \\
\hline
\end{tabular}

${ }^{\mathrm{a}}$ For assumptions, see section 2 .

At $47^{\circ} \mathrm{S}$, Fe-mediated changes in chlorophyll $a$ and other properties appeared to be independent of mean light levels in the high- or low-light treatments. If the resident population was Fe-limited at $47^{\circ} \mathrm{S}$ (ambient DFe was $<0.1 \mathrm{nmol} \mathrm{L}^{-1}$ ), it is puzzling that there were only slight increases in chlorophyll $a$ or cyanobacterial abundance in the control $\left(0.3 \mathrm{nmol} \mathrm{L}^{-1} \mathrm{Fe}\right)$ and/or in the low-Fe $\left(0.5 \mathrm{nmol} \mathrm{\textrm {L } ^ { - 1 }} \mathrm{Fe}\right)$ treatments. It should be noted that these DFe levels in the carboys are the maximum possible levels (see Table 2 legend). Moreover, while small eukaryotes have been shown to have lower algal Fe requirements than large cells [Sunda and Huntsman, 1997], there is evidence of high $\mathrm{Fe}$ requirements for cyanobacteria from labcultured studies [Brand, 1991], although field data are lacking. Raven [1990] and, more recently, Behrenfeld and Kolber [1999] report that this may be due to high PSI:PSI ratios in cyanobacteria.

On the basis of experiments with algal cultures, Sunda and Huntsman [1997] report that iron limitation and light limitation of algal growth are integrally linked. At the $54^{\circ} \mathrm{S}$ site, in the absence of a high-light control treatment and with evidence of Fe contamination in all carboys is it possible to comment on the Fe status of the resident cells? Phytoplankton under ambient conditions at $54^{\circ} \mathrm{S}$ displayed evidence of nutrient stress $\left(F_{v} / F_{m}=0.25\right)$ consistent with low-Fe levels. Furthermore, the expression of the molecular marker for algal Fe stress, flavodoxin [LaRoche et al., 1996], was highest along the $142^{\circ} \mathrm{E}$ meridian at $54^{\circ} \mathrm{S}$ where it was tenfold greater than was observed in the Subtropical Frontal Zone (J. LaRoche, personal communication, 2000). Thus there is evidence of an Festressed algal community at $54^{\circ} \mathrm{S}$. Despite this Fe stress, which should result in depressed cellular chlorophyll $a$ content [see Greene et al., 1991; Vassiliev et al., 1995], this was not observed at $54^{\circ} \mathrm{S}$ where the resident cells had tenfold higher cellular chlorophyll $a$ levels, indicative of increased light-harvesting capability, than at $47^{\circ} \mathrm{S}$.

In other deckboard Fe enrichment experiments conducted in the Southern Ocean [see de Baar and Boyd, 2000] the addition of $\mathrm{Fe}$ to carboys results in elevated chlorophyll $a$ levels. This was not the case in the treatments ( 1 and $3 \mathrm{nM} \mathrm{Fe}$, final concentration) incubated under conditions of mean in situ irradiances. In order to resolve the observed lack of a response by Fe-stressed phytoplankton to elevated Fe supply the effects of low light levels must be considered. Raven [1990] estimated that the Fe requirements of lab-cultured cells growing under light limitation were fiftyfold higher than under light-saturated growth. In the present experiments a $3 \mathrm{nM}$ Fe enrichment represents a greater than thirtyfold increase in DFe levels relative to ambient levels. Thus, at the mean light levels simulating a $90 \mathrm{~m}$ MLD (low-light Fe-replete treatments) such $\mathrm{Fe}$ enrichment will likely be insufficient to alleviate algal Fe stress (this calculation is problematic due to uncertainties about the nature of bioavailable Fe [Wells et al., 1995]).

In contrast, in the high-light Fe-replete treatments there were large increases in cellular chlorophyll $a$. Such a trend suggests alleviation of $\mathrm{Fe}$ stress [Greene et al., 1991] since cellular chlorophyll $a$ content increased even though cells received higher than mean in situ irradiances. The latter should lead to decreased light-harvesting requirements and would tend to decrease cellular chlorophyll $a$ [Van Leeuwe, 1996, and references therein]. These findings point to the simultaneous limitation of algal growth at the $54^{\circ} \mathrm{S}$ site by light climate/Fe supply. Low mean irradiances, because of the deeper MLD, considerably elevated the algal $\mathrm{Fe}$ requirements of the resident cells in these low $\mathrm{Fe}$ waters and hence, by setting algal $\mathrm{Fe}$ quotas in this HNLSLC region, were a key determinant of phytoplankton growth at $54^{\circ} \mathrm{S}$ (under silicic acid-replete conditions). Because of the integral nature of Fe/light colimitation and the limited nature of the present data set, it is not possible to ascertain the relative contributions of irradiance and $\mathrm{Fe}$ supply to the control of algal growth. This subject requires further research in SA waters.

Table 3b. Phytoplankton Growth Rates (Doublings $\mathrm{d}^{-1}$ ) Estimated From Instantaneous Changes in Cell Abundances (Net Growth) ${ }^{\mathrm{a}}$

\begin{tabular}{lrrrrrr}
\hline & \multicolumn{3}{c}{$47^{\circ} \mathrm{S}$} & \multicolumn{3}{c}{$54^{\circ} \mathrm{S}$} \\
\cline { 2 - 6 } \multicolumn{1}{c}{ Treatment } & $t=2$ & $t=4$ & $t=7$ & $t=2$ & $t=6$ & $t=10$ \\
\hline Control & -0.05 & 0.00 & 0.10 & -0.05 & 0.10 & 0.06 \\
Low-Fe/low-light & -0.04 & 0.02 & 0.04 & 0.01 & 0.10 & 0.02 \\
High-Fe/low-light & 0.29 & 0.11 & 0.02 & 0.03 & 0.20 & 0.22 \\
Low-Fe/high-light & 0.02 & -0.05 & 0.154 & -0.02 & 0.27 \\
High-Fe/high-light & 0.21 & 0.25 & 0.08 & \\
\hline
\end{tabular}

${ }^{a}$ For assumptions, see section 2. 


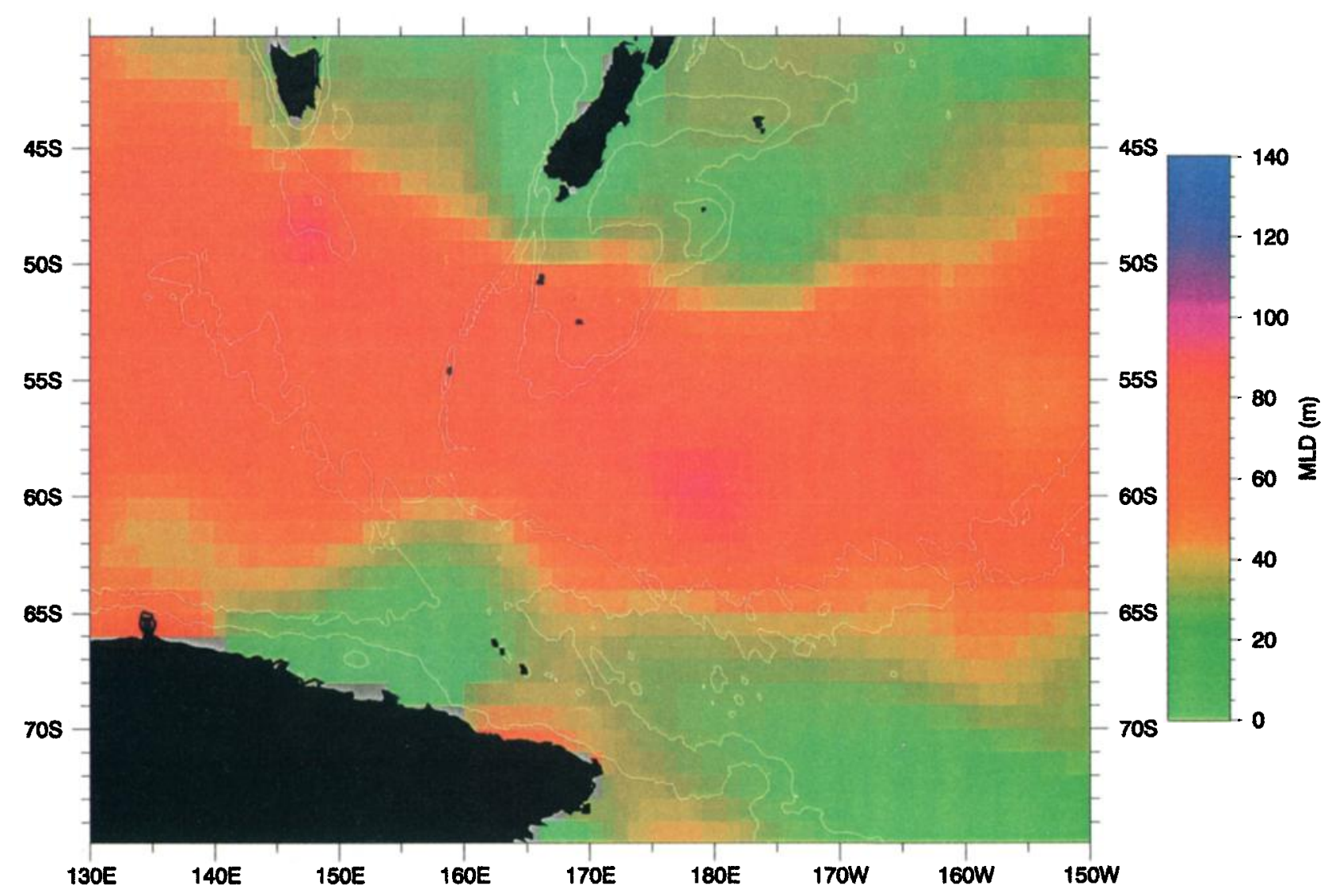

Plate 1. A plot of mean summer mixed layer depths (MLDs) for the Australasian-Pacific sector of the Southern Ocean $\left(130^{\circ} \mathrm{E}-150^{\circ} \mathrm{W}, 40^{\circ}-75^{\circ} \mathrm{S}\right)$ collated from the World Ocean Atlas. Supplied by M. Hadfield (National Institute of Water and Atmospheric Research, Wellington).

\subsection{Comparison With Other Iron/Light Perturbation Field Studies}

As far as is known, only five other Fe/light experiments have been conducted in the field, four in the Southern Ocean and one in the NE subarctic Pacific, where Maldonado et al. [1999] demonstrated $\mathrm{Fe} /$ light colimitation in a deckboard simulation of an $80 \mathrm{~m}$ MLD. They reported the highest chlorophyll $a$ levels in a high-Fe/high-light treatment and the lowest in a low-Fe/low-light treatment. This is consistent with the $54^{\circ} \mathrm{S}$ experiment (although there was no true low-Fe treatment at $54^{\circ}$ S). Maldonado et al. [1999] reported little change in $P_{\text {bmax }}$ over time in their experiments, which they attributed to the confounding influence on $P_{\mathrm{bmax}}$ of light limitation [Richardson et al., 1983] and Fe limitation [Greene et al., 1991]. In the present experiments, up to tenfold increases in cellular chlorophyll $a$ were observed, illustrating the pitfalls of using $P_{\text {bmax }}$ to express the maximum rate of photosynthesis [see Henley and Yin, 1998] and the need to normalize $P_{\max }$ to cell abundance.

Boyd et al. [1999] carried out a deckboard Fe enrichment in SA waters SE of New Zealand in austral spring (MLD $80 \mathrm{~m}$ ) at $10 \%-50 \% I_{0}$ and reported little change in chlorophyll $a(0.3$ $\left.\mu \mathrm{g} \mathrm{L}^{-1}\right)$ at $10 \% I_{0}$ after 5 days but increases to $0.7 \mu \mathrm{g}$ and $>1$ $\mu \mathrm{g} \mathrm{L}^{-1}$ in the 30 and $50 \% I_{0}$ carboys, respectively. These trends are similar to those observed for the $54^{\circ} \mathrm{S}$ experiment. Van Leeuwe [1996] examined the effects of Fe/light limitation on lab cultures of the Antarctic flagellate Pyraminomonas sp. from waters south of the PF. Van Leeuwe observed a decline in cellular pigment content due to Fe limitation, whereas light limitation induced an increase in cellular pigment content (which was less pronounced for Fe-deplete cells). During the SOIREE in situ mesoscale Fe enrichment, Boyd et al. [2000] also conducted deckboard $\mathrm{Fe}$ enrichments in which the mean light levels were varied. They reported that there was relatively little increase in chlorophyll concentrations in a treatment mimicking a $100 \mathrm{~m}$ mixed layer, relative to the observed greater than fifteenfold increases in treatments representing 65 and $40 \mathrm{~m}$ MLDs. These findings are in contrast to Takeda [1998], who reported no difference in growth rates (instantaneous change in chlorophyll $a$ levels) between Fe-enriched deckboard carboys ( $>1 \mathrm{nmol} \mathrm{L^{-1 }} \mathrm{Fe}$ added) incubated at $<5$ and $40 \% I_{0}$ in polar waters south of the PF. The reason for these different outcomes in deckboard Fe/light experiments in the Southern Ocean is not presently known.

\subsection{Estimating Algal Growth Rates in the Southern Ocean}

In deckboard Fe enrichments in the Ross Sea, Martin et al. [1990] reported increased algal (net) growth rates (chlorophyll $a$ specific) from 0.3 to 0.7 doublings $\mathrm{d}^{-1}$. In the $54^{\circ} \mathrm{S}$ experiment, chlorophyll $a$ specific growth rates increased to $>1$ doubling $\mathrm{d}^{-1}$ in high light treatments, thus exceeding the theoretical maximum growth rate at $4^{\circ} \mathrm{C}$ [Banse, 1991]. However, as cellular chlorophyll $a$ increased by up to tenfold in the $54^{\circ} \mathrm{S}$ experiment, growth rates cannot be reliably estimated using proxies such as chlorophyll $a$ in regions of the Southern Ocean 
where Fe/light colimitation of algal growth may exist. Estimates of net algal growth rate (cellular abundance and silica turnover) at $54^{\circ} \mathrm{S}$ suggest that growth rates under Fe-replete conditions were 0.25 doublings $\mathrm{d}^{-1}$.

\subsection{Seasonality in Factors Limiting Production in the Southern Ocean}

In the present $\mathrm{Fe} /$ light experiments all treatments were also enriched with silicic acid. The interactions between algal growth, Fe, and silicic acid are explored by Sedwick et al. [1999] and Hutchins et al. [this issue], who report evidence of $\mathrm{Fe} / \mathrm{Si}$ limitation at $47^{\circ} \mathrm{S}$ in March 1998. Quéguiner [this issue] also explores the possibility of silicic acid limitation. These findings, together, are indicative of seasonality in the factors limiting the growth of eukarotic phytoplankton in SA waters. In contrast, prokaryotic phytoplankton have higher iron quotas [Brand, 1991], have no requirement for silicic acid, and appear to be particularly sensitive to temperature [Marchant et al., 1987]; thus their growth rates will be limited by different environmental factors than those for eukaryotes.

As discussed by Boyd et al. [1999], the seasonal progression of the factors controlling the growth of eukaryotic phytoplankton in SA waters may be irradiance in winter, $\mathrm{Fe} /$ light in early spring and autumn when water column light levels are elevated because of shallower MLDs (caused by reduced wind stress), and higher incident irradiances [Bishop and Rossow, 1991]. If silicic acid levels are not limiting in spring, then Fe limitation will control growth, whereas in summer/early autumn, if the MLDs remain relatively shallow, $\mathrm{Fe}$ and silicic acid availability will probably control growth rates. At $54^{\circ} \mathrm{S}$ in March 1998, Fe, light, and silicic acid may have together limited algal growth. Although the effects of light limitation on Fe uptake [Sunda and Huntsman, 1997] and on silicic acid uptake [Nelson and Brzezinski, 1997; Brzezinski et al., 2001], and that of Fe limitation on silicic acid uptake [Hutchins and Bruland, 1998] have been demonstrated, the interrelationships between $\mathrm{Fe}$, light, and silicic acid limitation are less clear and require further study.

\begin{abstract}
Acknowledgments. We thank the officers and crew of R/V Aurora Australis for their skills at sea. We are grateful for assistance from the support staff and workshops at CSIRO (Hobart) and Antarctic Division (Hobart). Field support for this work was provided by ANARE (via ASAC proposal 1156). We acknowledge the efforts of Lisette Robertson and Michael Grose (Antarctic CRC, Hobart) for the shipboard analysis of samples for size-fractionated chlorophyll and Rick Van den Enden (Antarctic CRC, Hobart) for phytoplankton species identification. Vertical irradiance profiles, CTD, and macronutrient data were kindly provided by Don MacKenzie (CSIRO, Hobart), Mark Rosenberg (Antarctic CRC, Hobart), and Neil Johnson (Antarctic CRC, Hobart). We are grateful to Mark Hadfield (NIWA, Wellington) for the provision of a plot of mean summer mixed layer depths collated from the World Ocean Atlas and Julie LaRoche (Institut fur Meeresekunde, Kiel, Germany) for a personal communication. The comments of an anonymous reviewer and the editor greatly assisted in improving this manuscript. This research was supported by Antarctic CRC, Hobart, ANARE, Hobart, Australia. PB acknowledges the support of the New Zealand Government FRST programme via the Ocean Ecosystem project. DH acknowledges the support of NSF INT 9802132 for participation in this study. BQ the acknowledges French S.O. JGOFS (ANTARES program) and the Comité Français de Coopération Franco-Australienne en Sciences et Technologies Marines (IFREMER and INSU/CNRS).
\end{abstract}

\section{References}

Banse, $\mathbf{K}$., Rates of phytoplankton cell division in the field and in iron enrichment experiments, Limnol. Oceanogr., 36, 1866-1898, 1991.
Behrenfeld, M. J., and Z. S. Kolber, Widespread iron limitation of phytoplankton in the South Pacific Ocean, Science, 283, 840-843, 1999.

Berg, G. M., P. M. Glibert, and C.-C. Chen, Dimension effects of enclosures on ecological processes in pelagic systems, Limnol. Oceanogr., 44, 1331-1340, 1999.

Bishop, J. K. B., and W. R. Rossow, Spatial and temporal variability of global surface solar irradiance, J. Geophys. Res., 96, 16,839-16,858, 1991.

Boyd, P. W., D. Muggli, D. Varela, R. H. Goldblatt, R. Chretien, K. J. Orians, and P. J. Harrison, In vitro iron enrichment experiments in the NE subarctic Pacific, Mar. Ecol. Prog. Ser., 136, 179-196, 1996.

Boyd, P. W., J. LaRoche, M. Gall, R. Frew, and R. M. L. McKay, The role of iron, light, and silicate in controlling algal biomass in subAntarctic waters SE of New Zealand, J. Geophys. Res., 104, 13,395$13,408,1999$.

Boyd, P. W., et al., A mesoscale phytoplankton bloom in the polar Southern Ocean stimulated by iron fertilization, Nature, 407, 695702, 2000.

Brand, L. E., Minimum iron requirements of marine phytoplankton and the implications for the biogeochemical control of new production, Limnol. Oceanogr., 36, 1756-1771, 1991.

Brzezinski, M. A., and D. R. Philips, Evaluation of ${ }^{32} \mathrm{Si}$ as a tracer for measuring silica production rates in marine waters, Limnol. Oceanogr., 42, 856-865, 1997.

Brzezinski, M. A., T. A. Villareal, and F. Lipschultz, Silica production and the contribution of diatoms to new and primary production in the central North Pacific, Mar. Ecol. Prog. Ser., in press, 2001.

Coale, K. H., Effects of iron, manganese, copper and zinc enrichments on productivity and biomass in the subarctic Pacific, Limnol. Oceanogr., 36, 1851-1864, 1991.

Coale, K. H., et al., A massive phytoplankton bloom induced by ecosystem-scale iron fertilization experiment in the equatorial Pacific Ocean, Nature, 383, 495-501, 1996a.

Coale, K. H., S. E. Fitzwater, R. M. Gordon, K. S. Johnson, and R. T. Barber, Control of community growth and export production by upwelled iron in the equatorial Pacific Ocean, Nature, 379, 621-624, $1996 b$.

Crossley, A. C., Shipboard flow cytometric analysis of protist population structure in the Southern Ocean, paper presented at VII SCAR International Biological Symposium, Sci. Counc. for Antarctic Res., Christchurch, N. Z., 1998.

de Baar, H. J. W., and P. W. Boyd, The role of iron in plankton ecology and carbon dioxide exchange of polar and subpolar oceans, in JGOFS Symposium Volume, IGBP Books Ser., vol. 5, pp. 61-140, Cambridge Univ. Press, New York, 2000.

de Baar, H. J. W., J. T. M. de Jong, D. C. E. Bakker, B. M. Löscher, C. Veth, U. Bathmann, and V. Smetacek, Importance of iron for plankton blooms and carbon dioxide drawdown in the Southern Ocean, Nature, 373, 412-415, 1995.

Denman, K., and A. Gargett, Time and space scales of vertical mixing and advection of phytoplankton in the upper ocean, Limnol. Oceanogr., 28, 801-815, 1983 .

Dugdale, R. C., F. P. Wilkerson, and H. J. Minas, The role of a silicate pump in driving new production, Deep Sea Res., Part I, 42, 697-719, 1995.

Greene, R. M., R. J. Geider, and P. G. Falkowski, Effect of iron limitation on photosynthesis in a marine diatom, Limnol. Oceanogr., 36, 1772-1782, 1991.

Henley, W. J., and Y. Yin, Growth and photosynthesis of marine Synechococcus (Cyanophyceae) under iron stress, J. Phycol., 34, 94103, 1998.

Hutchins, D. A., and K. W. Bruland, Iron limited diatom growth and Si:N uptake ratios in a coastal upwelling regime, Nature, 393, 561$564,1998$.

Hutchins, D. A., P. N. Sedwick, G. DiTullio, P. W. Boyd, B. Quéguiner, F. B. Griffiths, and A. C. Crossley, Control of phytoplankton growth by iron and silicic acid availability in the subantarctic Southern Ocean: Experimental results from the SAZ Project, J. Geophys. Res., this issue.

Joint, I. R., and A. J. Pomroy, Production of picoplankton and small nanoplankton in the Celtic Sea, Mar. Biol., 77, 19-27, 1983.

Joint, I., A. Pomroy, G. Savidge, and P. Boyd, Size-fractionated primary productivity of the NE Atlantic in May-June 1989, Deep Sea Res., Part II, 40, 423-440, 1993.

Kolber, Z., and P. G. Falkowski, Use of active fluorescence to estimate 
phytoplankton photosynthesis in situ, Limnol. Oceanogr., 38, 1646$1665,1993$.

Kolber, Z. S., R. T. Barber, K. H. Coale, S. E. Fitzwater, R. M. Greene, K. S. Johnson, S. Lindley, and P. G. Falkowski, Iron limitation of phytoplankton photosynthesis in the equatorial Pacific Ocean, $\mathrm{Na}$ ture, 371, 145-149, 1994.

LaRoche, J., P. W. Boyd, R. M. L. McKay, and R. J. Geider, Flavodoxin as an in situ marker for iron stress in phytoplankton, Nature, $382,802-805,1996$.

Lippemeier, S., P. Hartig, and F. Colijn, Direct impact of silicate on the photosynthetic performance of the diatom Thalassiosira weissflogii assessed by on- and off-line PAM fluorescence measurements, J. Plankton Res., 21, 269-283, 1999.

MacIntyre, S., Turbulent mixing and resource supply to phytoplankton, in Physical Processes in Lakes and Oceans, Coastal Estuarine Stud., vol. 54, edited by J. Imberger, pp. 561-590, AGU, Washington, D. C., 1998.

Mackey, D. J., J. Parslow, H. W. Higgins, F. B. Griffiths, and J. E. O'Sullivan, Plankton productivity and biomass in the western equatorial Pacific: Biological and physical controls, Deep Sea Res., Part I, 42, 499-533, 1995.

Marchant, H. J., A. T. Davidson, and S. W. Wright, The distribution and abundance of chroococcoid cyanobacteria in the Southern Ocean, Proc. NIPR Symp. Polar Biol., 1, 1-9, 1987.

Martin, J. H., R. M. Gordon, S. E. Fitzwater, and W. W. Broenkow, VERTEX: Phytoplankton/iron studies in the Gulf of Alaska, Deep Sea Res., Part A, 36, 649-680, 1989.

Martin, J. H., S. E. Fitzwater, and R. M. Gordon, Iron deficiency limits phytoplankton growth in Antarctic waters, Global Biogeochem. Cycles, 4, 5-12, 1990.

Maldonado, M., P. W. Boyd, N. M. Price, and P. J. Harrison, Colimitation of phytoplankton growth by light and Fe during winter in the subarctic Pacific Ocean, Deep Sea Res., Part II, 46, 2475-2486, 1999

Mitchell, B. G., E. A. Brody, O. Holm-Hansen, C. McClain, and J. Bishop, Light limitation of phytoplankton biomass and macronutrient utilization in the Southern Ocean, Limnol. Oceanogr., 36, 1662$1677,1991$.

Nelson, D. M., and M. A. Brzezinski, Diatom growth and productivity in an oligotrophic midocean gyre: A 3-yr record from the Sargasso Sea near Bermuda, Limnol. Oceanogr., 42, 473-486, 1997.

Nelson, D. M., and W. O. Smith Jr., Sverdrup revisited: Critical depths, maximum chlorophyll levels, and the control of Southern Ocean productivity by the irradiance-mixing regime, Limnol. Oceanogr., 36, 1650-1661, 1991.

Olson, R. J., E. R. Zettler, and M. D. DuRand, Phytoplankton Analysis Using Flow cytometry, in Handbook of Methods in Aquatic Microbial Ecology, edited by P. F. Kemp et al., pp. 175-186, A. F. Lewis, New York, 1993.

Paasche, E., Silicon and the ecology of marine planktonic diatoms, 1, Thalassiosira pseudonana (Cyclotella nana) grown in chemostats with silicate as the limiting nutrient, Mar. Biol., 19, 117-126, 1973.

Quéguiner, B., Biogenic silica production in the Australian sector of the Subantarctic Zone of the Southern Ocean in late summer 1998, J. Geophys. Res., this issue.

Raven, J. A., Predictions of Mn and Fe use efficiencies of phototrophic growth as a function of light availability for growth and C assimilation pathway, New Phytol., 116, 1-17, 1990.

Richardson, K., J. Beardall, and J. A. Raven, Adaptation of unicellular algae to irradiance: An analysis of strategies, New Phytol., 93, 157$191,1983$.

Rintoul, S. R., and T. W. Trull, Seasonal evolution of the mixed layer in the Subantarctic Zone south of Australia, J. Geophys. Res., this issue.

Rintoul, S. R., J. R. Donguy, and D. H. Roemmich, Seasonal evolution of upper ocean thermal structure between Tasmania and Antarctica, Deep Sea Res., Part I, 44, 1185-1202, 1997.
Schmidt, M. A., and D. A. Hutchins, Size-fractionated biological iron and carbon uptake along a coastal to offshore transect in the NE Pacific, Deep Sea Res., Part II, 46, 2487-2503, 1999.

Sedwick, P. N., P. R. Edwards, D. J. Mackey, F. B. Griffiths, and J. S. Parslow, Iron and manganese in surface waters of the Australian subantarctic region, Deep Sea Res., Part I, 44, 1239-1253, 1997.

Sedwick, P. N., G. R. DiTullio, D. A. Hutchins, P. W. Boyd, F. B. Griffiths, T. W. Trull, and B. Queguiner, Limitation of algal production by iron deficiency in the Australian sector of the subantarctic Southern Ocean, Geophys. Res. Lett., 26, 2865-2868, 1999.

Sunda, W. G., and S. A. Huntsman, Interrelated influence of iron, light and cell size on marine phytoplankton growth, Nature, 390, 389-392, 1997.

Takeda, S., Influence of iron availability on nutrient consumption ratio of diatoms in oceanic waters, Nature, 393, 774-777, 1998.

Timmermans, K. R., et al., Iron stress in the Pacific region of the Southern Ocean: Evidence from enrichment assays, Mar. Ecol. Prog. Ser., 166, 27-41, 1998.

van Leeuwe, M. A., A Barren Ocean, iron and light interactions with phytoplankton growth in the Southern Ocean, Ph.D. thesis, 189 pp., Univ. of Groningen, Groningen, Holland, 1996.

Vassiliev, I. R., Z. Kolber, K. D. Wyman, D. Mauzerall, V. K. Shukla, and P. G. Falkowski, Effects of iron limitation on photosystem, II, Composition and light utilisation in Dunaliella tertiolecta, Plant Physiol., 109, 963-972, 1995.

Wells, M. L., N. M. Price, and K. W. Bruland, Iron chemistry in seawater and its relationship to phytoplankton: A workshop report, Mar. Chem., 48, 157-182, 1995.

Wright, S. W., S. W. Jeffrey, R. F. C. Mantoura, C. A. Llewellyn, T. Bjornland, D. Repeta, and N. A. Welschmeyer, Improved HPLC method for the analysis of chlorophylls and carotenoids from marine phytoplankton, Mar. Ecol. Prog. Ser., 77, 183-196, 1991.

Wright, S. W., R. L. Waters, R. L. van den Enden, P. Scott, P. G. Strutton, A. C. Crossley, H. J. Marchant, F. B. Griffiths, and P. I. Bonham, Phytoplankton populations in the Southern Ocean: Distribution, abundance, productivity and composition during Jan-Mar, 1996, paper presented at Annual Conference, Australıan Mar. Sci. Assoc., Hobart, Tasmania, 1996.

Zentara, S. J., and D. Kamykowski, Geographic variation in the relationship between silicic acid and nitrate in the South Pacific Ocean, Deep Sea Res., Part A, 28, 455-465, 1981.

P. W. Boyd, Centre for Chemical and Physical Oceanography, National Institute of Water and Atmospheric Research, Department of Chemistry, University of Otago, Dunedin, 9001 New Zealand. (pboyd@alkali.otago.ac.nz)

A. C. Crossley, Institute of Antarctic and Southern Ocean Studies, University of Tasmania, P.O. Box 252-77, Hobart, Tasmania 7001, Australia.

G. R. DiTullio, Grice Marine Laboratory, University of Charleston, 205 Fort Johnson, Charleston, SC 29412, USA.

F. B. Griffiths, CSIRO Division of Marine Research, GPO Box 1538, Hobart, Tasmania 7001, Australia.

D. A. Hutchins, College of Marine Studies, University of Delaware, 700 Pilottown Road, Lewes, DE 19958, USA.

B. Queguiner, Laboratoire d'Oceanographie et de Biogeochimie, Centre d'Oceanographie de Marseille, UMR CNRS 6535, Parc Scientifique et Technologique de Luminy, Case 901, F-13288 Marseille Cedex 09, France.

P. N. Sedwick and T. W. Trull, Antarctic CRC, GPO Box 252-80, Hobart, Tasmania 7001, Australia.

(Received March 30, 2000; revised May 8, 2001; accepted May 21, 2001.) 